\section{Wittgenstein's paranoia}

SIR - The recent debate in Nature between Greenfield and Marshall' ${ }^{1}$ over the merits of Wittgenstein again shows that some people regard him as the greatest philosopher of the century, others as just one of a long line of German-speaking philosophers (such as Hegel and Heidegger) who have dazzled some innocent English-speaking philosophers by writing material whose basic nonsense is concealed by the impenetrable thickets of the German language. I would like to advance a third hypothesis. Russell in his autobiography (among others) draws attention to Wittgenstein's schizoid and paranoid personality. Canon C. E. Raven (who was vice-chancellor of the University of Cambridge during Wittgenstein's tenure of his chair there) told me that Wittgenstein at times actually suffered from paranoid delusions and would flee to outlying villages to escape from his imaginary enemies.

Certain schizoid personalities develop the ability to write in a form of speech disorder known as schizophrenese. In some cases this is by no means nonsense, but can have a powerful emotional and aesthetic appeal it is in fact a kind of poetry, based on powerful allegorical and metalogical (not logical) associations. A well-known example in literature is Finnegan's Wake. Joyce himself was never overtly schizophrenic, although very schizoid, and his daughter developed the illness; but he must have been near enough to it to be able to write schizophrenese (which normal people find almost impossible to do). One essence of schizophrenese is that the meaning of a statement is never quite contained within the statement but lies somehow 'behind' it and when searched for continually retreats behind any further elucidating statements - a phenomenon that Wittgenstein's philosophical writings exhibit to a singular degree. In his book on Wittgenstein ${ }^{2}$, Ayer, with his clear logical mind, makes attempt after attempt to understand what Wittgenstein is getting at - and continually fails, as he himself admits. I suggest that this is because Wittgenstein should be read as poetry and not as the kind of philosophy practised by Ayer and his intellectual forebears in the British empiricist tradition.

Wittgenstein's influence was also due to his remarkable hypnotic, even demonic, personality - Ayer told me that all the philosophers at Cambridge, except Broad, were terrified of him - and to his ferocious and overbearing style of philosophical debate. This is also documented by Teichman ${ }^{3}$. I had no personal contact with Wittgenstein (although my cousin Yorick Smythies was one of the Inner Circle), but when I was a research student at the Psychological Laboratory at Cambridge in the 1950 s I used to attend the weekly meetings of Wittgenstein's disciples. I found myself unable to make any sense of the tortuous, not to say tormented, wrestlings with the thoughts produced by in- spired members of the group in imitation of the Master's style. But, as a psychiatrist, I found them very like the thoughts and modes of thinking that troubled my schizophrenic patients.

Lastly, Wittgenstein's method was essentially based on an analysis of what he regarded as 'ordinary English usage'. Churchland ${ }^{4}$ has recently subjected this method to a devastating attack on the grounds that such 'folk psychology' is very unlikely to tell us anything true or interesting about the mind or about perception. One sympathizes with philosophers in their desperate defence of their turf against the continual inroads made upon it by the advances of neuroscience, perceptual science, cognitive science and perhaps an extended physics ${ }^{5,6}$ (from which sources our only true understanding of the mind can come); but to base this defence on such as Wittgenstein cannot advance their cause.

\section{The National Hospital}

J. R. SMYTHIES

for Neurology and Neurosurgery,

Queen Square, London WC1N 3BG, UK

1. Greenfield, A. J., Marshall, J. C. Nature 348, 384 (1990)

2. Ayer. A. J. Wittgenstein (Weidenfeld \& Nicholson. London, 1985).

3. Teichman, J. Philosophy and the Mind. 51 (Blackwell, Oxford, 1988)

4. Churchland, P. S. Neurophilosophy (MIT Press. Cambridge, 1986).

5. Penrose, R. The Emperor's New Mind (Oxford University Press, 1989).

6. Smythies, J.R. The Walls of Plato's Cave 6 (in the press).

\section{So what's new?}

$\mathrm{S}_{\mathrm{IR}}$ - A feature that distinguishes scientific journals from breakfast-cereal boxes is a preference for the word 'novel' over terms such as 'brand new'. This preference is accelerating, as is evident from the figure, where the frequency of 'novel' in titles and abstracts catalogued in Medline is compared to the frequency of a control word ('control')

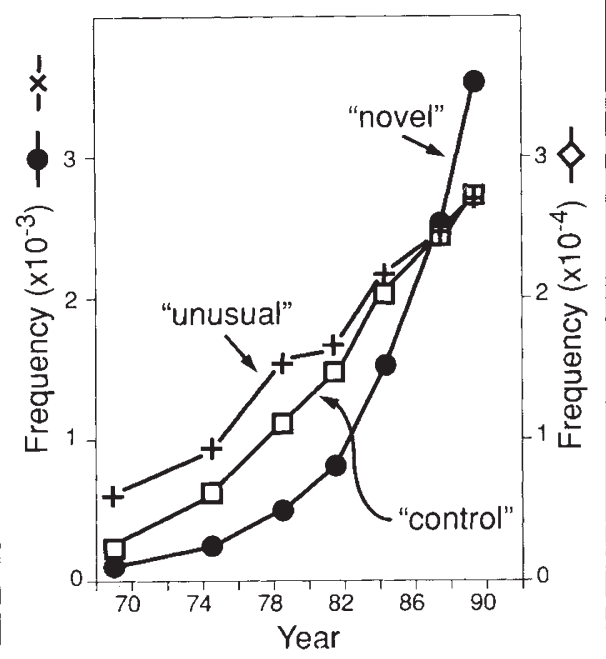

over the past 25 years. The recent popularity of 'novel' is likely to be an inflationary increase rather than an explosion in the number of extraordinary discoveries. For one thing, the increase appears to come at the expense of less conspicuous synonyms, such as 'unusual', which shows a decline in popularity relative to 'control'. For another, 'novel' is especially favoured in journals that are noted more for solid science than for novelty. In the most recent month for which information is available, the Journal of Biological Chemistry and FEBS Letters each accounted for twice as many 'novel' papers (10) as the combined total for Nature, Science and Cell.

If this expanding use of 'novel' is allowed to continue unchecked, one can foresee that in the near future its presence on a paper will be de rigueur, and the word will lose its meaning entirely. To prevent this from happening, we recommend that authors reserve 'novel' for strikingly new discoveries and consider more appropriate terms to describe observations that range from somewhat atypical to unusual. We should also keep in mind that at the supermarket, novelties often end up at the rear of the ice-cream freezer.

$$
\text { Steven HenikofF* }
$$
RoBERT LEVIS

* Howard Hughes Medical Institute and Basic Sciences Division,

Fred Hutchinson Cancer Research Center,

Seattle,

Washington 98104, USA

\section{New money}

SIR - Whenever a new 'big science' megaproject is proposed, we are always reassured by the project's proponents that it will not adversely affect other areas of research because it will be financed with 'new money'. This term has been used so freely and so often that it is about time that someone asked precisely what 'new money' is supposed to mean. Surely the US government is not planning to finance the human genome project by printing 3,000 million new one dollar bills or the Superconducting Super Collider with 822,400 million newly minted pennies?

Perhaps George "read-my-lips" Bush will propose some more new taxes to produce this 'new money', or perhaps it will come from other non-science programmes such as food stamps or Medicare?

Physicists believe in the law of the conservation of energy. They would be the first to ridicule anyone claiming to have a perpetual motion machine that could produce "new energy' out of nothing. Nevertheless, they expect us to believe their fable about 'new money'.

ROBERT J. YAES University of Kentucky Medical Center, Department of Radiation Medicine, 800 Rose Street, Lexington, Kentucky 405036-0084, USA 